Media Industries 6.1 (2019)

\title{
Broadway Is a Two-Way Street: Integrating Hollywood Distribution and Exhibition
}

\author{
Laura E. Felschow ${ }^{1}$ \\ SUNY ONEONTA \\ Laura.Felschow $[\mathrm{AT}]$ oneonta.edu
}

\begin{abstract}
This article investigates connections across the theater, film, and television industries in order to complicate traditional media studies approaches to Broadway. In particular, this piece focuses on the development of streaming services such as BroadwayHD and Broadway Near You, theatrical exhibition via Fathom Events, and ventures such as Broadway Asia that mirror the US film industry's address of the growing Chinese audience. Broadway's attempts to integrate Hollywood's methods of distribution and exhibition demonstrate that the boundary between these industries is blurring, and therefore demanding further engagement between the fields of theater and media industries studies.
\end{abstract}

Keywords: Distribution, Exhibition, Broadway, Streaming

Since the economic turnaround of Broadway in the mid-to-late 1990s, the industrial relationship between the Great White Way and Hollywood has grown increasingly complex. ${ }^{2}$ While the "Disneyfication" of Broadway is oft discussed as the primary contemporary example of the US film industry's effects on the formerly faltering American theater scene, Broadway has in recent years turned to Hollywood for models of distribution and exhibition in hopes of expanding their traditionally narrow audience. ${ }^{3}$ With the mainstream success of Lin-Manuel Miranda's Hamilton, ${ }^{4}$ the highly rated if critically lambasted television productions of timetested musicals such as The Sound of Music Live! (National Broadcasting Company [NBC] 2013), Grease Live! (Fox 2016), and Jesus Christ Superstar Live! (NBC 2018), and plans for productions of Bye Bye Birdie Live! (NBC 2019) and Rent (Fox 2019), broader public interest in Broadway productions has been reinvigorated. ${ }^{5}$ For the 2017-2018 Broadway season, the Broadway League reported a total of 1,624 playing weeks, US\$1.69 billion in gross box office sales (up 17.1 percent from 2016 to 2017) and total attendance of 13,792,614 (up 3.9 percent from 2016 to 2017), making it the highest grossing and best attended season in Broadway recorded history. ${ }^{6}$ 
Looking to capitalize on this cultural and economic resurgence, Broadway has taken its lead from the US film and television industries by utilizing three distinct methods: digitally distributing theatrical content via streaming platforms, promoting "special event" theatrical exhibition of filmed plays and musicals, and targeting appeals to the booming Chinese entertainment market. As Broadway begins integrating the distribution and exhibition methods of the media industries, I argue that it is necessary for media industries scholars to open disciplinary boundaries that traditionally exclude the theater industry and consider the ways in which Broadway's industrial strategies are increasingly mirroring the industrial operations of film and television.

In this essay, I first outline how an approach drawn from media industries studies is particularly well-suited to understanding Broadway as an industry, highlighting the ways in which "Broadway" as a unifying, geographical term belies an intricate network of ownership and production that increasingly intertwines theater with other media industries. I then investigate the recent development of streaming services dedicated solely to musical theater and plays. I also discuss Broadway Near You and Fathom Events with regard to "special event" theatrical exhibition. Lastly, I explore the potential exploitation of the Chinese entertainment market via ventures that mirror the US film industry's targeted address of the Chinese audience, as well as efforts by Sino-US marketing partnerships to reach Chinese tourists in the United States. By looking at the US theater industry through a media industries lens, I demonstrate how the boundary between the theater and media industries is growing more permeable and establish some foundational groundwork necessary for more sustained attention to Broadway from media industries scholars.

\section{Broadway and Media Industries Studies}

There is a long history of interaction between the media industries and Broadway. Since the advent of the motion picture, the film industry has looked to the theater for both performers and content, with early motion pictures capitalizing on vaudeville and theatrical plays. In the 1950s, television became another avenue for musical theater, particularly because New York City was at the time the central hub of television production. With easy access to the city's vast network of performers and current stage productions, variety shows with comedy and music quickly became television staples. Examples include The Texaco Star Theatre (NBC 1948-1956), Cavalcade of Stars (DuMont 1949-1952, later renamed The Jackie Gleason Show CBS 1952-1957), and Your Show of Shows (NBC 1950-1954). Furthermore, Broadway actors frequented popular programs like The Ed Sullivan Show (CBS 1948-1971) and later The Tonight Show Starring Johnny Carson from 1962 until the program re-located to Burbank, California in 1972.

The flow from stage-to-screen also occurred in the reverse direction, as original film musicals were utilized as source material for Broadway shows, such as the 1980 production of 42nd Street or the 1988 production of Fame. Non-musical source material was also adapted from film to stage-for example, the 1982 production of Nine, based on Fellini's 81/2 (1963), or the 2002 production of Hairspray, based on the 1988 film-both of which, in demonstration of the Broadway/Hollywood loop, were turned into film musicals in the late 2000s. Furthermore, the aforementioned list of live television productions of hit musicals such as 
Grease Live! have brought musical theater back into the home in a manner not seen since the late 1950s and early 1960s with the likes of Mary Martin's telecast performance of Peter Pan (1960). Plays also have been adapted for the screen-adaptations of Shakespeare, Tennessee Williams, Arthur Miller, and Neil Simon abound. Examples include Frank Capra's 1944 film of Joseph Kesselring's 1938 play Arsenic and Old Lace to Mike Nichols' 1966 adaptation of Edward Albee's 1962 play Who's Afraid of Virginia Woolf? to the 2016 film version of August Wilson's 1985 play Fences.

In media studies, the study of theater is traditionally considered outside the purview of the field unless the performance is transmitted live, recorded/filmed, or adapted to another medium. Adaptations such as those above have been of primary concern for media studies scholars, focusing on issues of genre, aesthetics, and performance-particularly issues of faithfulness to the theatrical text. ${ }^{7}$ While it is worthwhile to look at these points of connection and intersection in terms of adaptation and movement of creative personnel across forms, limiting the scope of cross-industry study to these parameters misses integral pieces of a larger picture. Only a few texts, namely William Goldman's The Season: A Candid Look at Broadway, Steven Adler's On Broadway: Art and Commerce on the Great White Way, and Timothy White's Blue-Collar Broadway: The Craft and Industry of American Theater, take on the functionality of the industry itself. Jack Viertel has outlined the conventions of a Broadway show in The Secret Life of the American Musical, Michael Reidel's Razzle Dazzle provides an historical overview of Broadway's development and key theater owners and producers, while Ethan Mordden's When Broadway Went to Hollywood concentrates mostly on songwriters and their movement between the theatrical industry in New York and the film industry in California. Scholars such as Rick Altman, Jane Feuer, and Barry Keith Grant, as well as the two collections edited by Steven Cohan, have offered thorough surveys of the Hollywood film musical genre in terms of its construction and content, while prominent Hollywood film musicals such as West Side Story have multiple texts devoted to chronicling their success. Kelly Kessler's forthcoming book, Broadway in a Box: Television's Lasting Love Affair with the Musical provides a much-needed history of television's engagement with musicals, but by and large media studies scholars have remained focused on the musical in terms of film genre.

The overall tendency by scholars to place emphasis on generic markers too often results in a narrow focus on textual analysis while setting aside the industrial factors involved in negotiating between two different cultural industries. By looking exclusively at the texts, one risks missing other points of connection that illustrate the relationship between Hollywood and Broadway in equally productive ways. This gap testifies to the importance of re-thinking how we approach the study of Broadway and creates an inviting space for media industries scholars to explore the increasingly complex ways the theater and media industries interact beyond the exchange of intellectual property (IP) and creative personnel.

According to media industries scholar Paul McDonald, media industry studies is a subfield that "revels in disciplinary heterogeneity." ${ }^{8}$ As McDonald points out, this does not mean that media industry studies is without limits, but that media industry scholars often employ diverse theoretical and methodological approaches. A similar point is made by the editorial collective of Media Industries: While media industry studies has its 
origins in more quantitative approaches to political economy, it has expanded to include "discursive, ethnographic, and conjunctural analysis along with investigations of labor practices, networks of production, urban and economic geography, genealogies of media policy and ownership, and the politics of difference in institutional settings and sites of circulation." "Media industry studies, then, has capitalized on its foundations in political economy, sociology, and historiography to encompass the effects of media law and policy, the development of informal media economies, and issues stemmings from distinct production cultures and working conditions. In other words, media industry studies draws from both political economy and cultural studies in order to gain a more complex and multi-dimensional understanding of how media industries function. Matthew Freeman underscores this point in Industrial Approaches to Media where he characterizes the subfield to include more than the analysis of the economic drives or business structures of media. In addition to taking up questions about ethics and ideology, exploring tensions in managing both creativity and commerce, and investigating the contexts in which media work takes place, many media industries scholars have productively collaborated with or advocated for change within media industry institutions themselves, as a built-in aspect of their research programs. ${ }^{10}$ Media industry scholars continue to advance the contours of the discipline as the media industries contend with rapid change and expansion, actively engage with the consequences of globalization, digitization, corporate convergence, channel and platform proliferation, and the increasingly blurry lines between producers and consumers. ${ }^{11}$

Yet, media industry studies has only just begun to consider the ways in which the theater as an industry has shaped and has been shaped by the media industries. Apart from Shin Dong Kim's work on the musical theater industry in China, the topic of the theatrical industry's relationship to the media industries remains understudied. ${ }^{12}$ While Broadway may not be a popular consideration for media industries studies at this juncture, the field nevertheless accommodates a research tradition that positions distinct cultural industries in conversation with each other, such as Michele Hilmes' Hollywood and Broadcasting: From Radio to Cable (1999), which provides a cultural history of broadcasting across multiple media, and Cynthia B. Meyers' A Word From Our Sponsors: Admen, Advertising, and the Golden Age of Radio (2013), which explores the ways in which the advertising industry was an integral source of radio entertainment in the 1920s through 1940s.

This intellectual flexibility of media industry studies makes it particularly easy to broaden discussion of media industries to include Broadway. It entails looking at the networks of ownership and production, the importance of geography to its industrial identity, and the economic structures that have shaped the theater industry's development, particularly in terms of licensing, publishing, and other means of circulation. In what follows, then, I investigate how Broadway has been discursively constructed as a cohesive industry through the use of geography. I identify the key companies and players that constitute the US theater industry and the labor unions that shape its work force. After discussing how Broadway has extended beyond its theatrical home base via publishing and licensing, I conclude with a look at how the forces of media conglomeration and investment from companies outside the theater industry have ushered in an era of increasingly close ties between the theater industry and other media industries. 


\section{Understanding "Broadway"}

The term Broadway has come to signify the US theater industry as specifically tied to the geographical location of the Theater District in New York City. While theater in the United States certainly extends beyond a few blocks in Manhattan, Broadway is usually utilized as metonymic term for the entire US theater industry, and thus Broadway is viewed as a cohesive whole when it is in fact no singular organization or company. Nevertheless, since the mid-1800s, the area surrounding Times Square has been the epicenter of the US theater culture, much like London's West End is the hub of theater culture in the United Kingdom. Bordered by 40th Street to the south, 54th Street to the north, 6th Avenue to the east, and 9th Avenue to the west, Broadway consists of forty mostly commercial theaters with seating capacities of 499 or more. Theaters with seating capacities of 99-499 seats generally are considered Off-Broadway, while theaters fewer than 99 seats are usually labeled as Off-OffBroadway. ${ }^{13}$ Although most Off-Broadway and Off-Off-Broadway theaters are located elsewhere in New York City, there are a few located on or near midtown Broadway itself, while Broadway theaters are not necessarily on the street of Broadway, but in the Theater District on side streets near Broadway (see Figure 1).

The theaters labeled as Broadway typically mean bigger stages, resulting in the ability to launch more spectacular productions. The larger scale of Broadway productions often means that ticket prices are higher, and workers and performers are paid more. Thus, the Broadway, Off-Broadway, and Off-Off-Broadway distinctions mainly developed out of necessity because of the ways unions needed to differentiate contracts and pay scales. ${ }^{14}$ There can be movement between these three categories, which occurs mostly when hugely successful Off-Broadway shows such as Rent or Hamilton make the move to Broadway to play to larger houses.

Most producers and theater owners belong to The Broadway League (https://www.broad wayleague.com/), a national trade organization responsible for negotiating collective bargaining agreements and contracts with theatrical unions and guilds-such as the Actors' Equity Association (AEA), the Stage Directors and Choreographers Society (SDC), and United Scenic Artists (USA). The Broadway League also serves "the various needs of theatrical producers in New York and of national touring shows, as well as presenters of touring productions in cities throughout North America [and supports] the creation of profitable theatrical productions." ${ }^{\text {"15 }}$ Founded in 1930 as The League of New York Theaters, The Broadway League's more than 700 members include "theatre owners and operators, producers, presenters, and general managers in North American cities, as well as suppliers of goods and services to the commercial theatre industry. ${ }^{.16}$ The Broadway League works with the American Theater Wing to co-administer the Tony Awards, along with other promotional events, marketing initiatives, corporate sponsorships, and audience development programs designed to foster public interest in Broadway. The Broadway League does not represent all Broadway theaters, however. Disney, which owns the New Amsterdam Theatre, negotiates its own contracts with theatrical unions. Non-profit theater companies such as the Lincoln Center Theater, the Manhattan Theatre Club, the Roundabout Theatre Company, and the Second Stage Theatre belong to the League of Resident Theatres, which also negotiate with theatrical unions separately. ${ }^{17}$

Although there are some theaters that are individually owned either by large corporations or smaller not-for-profit organizations, three principal organizations own the majority of 


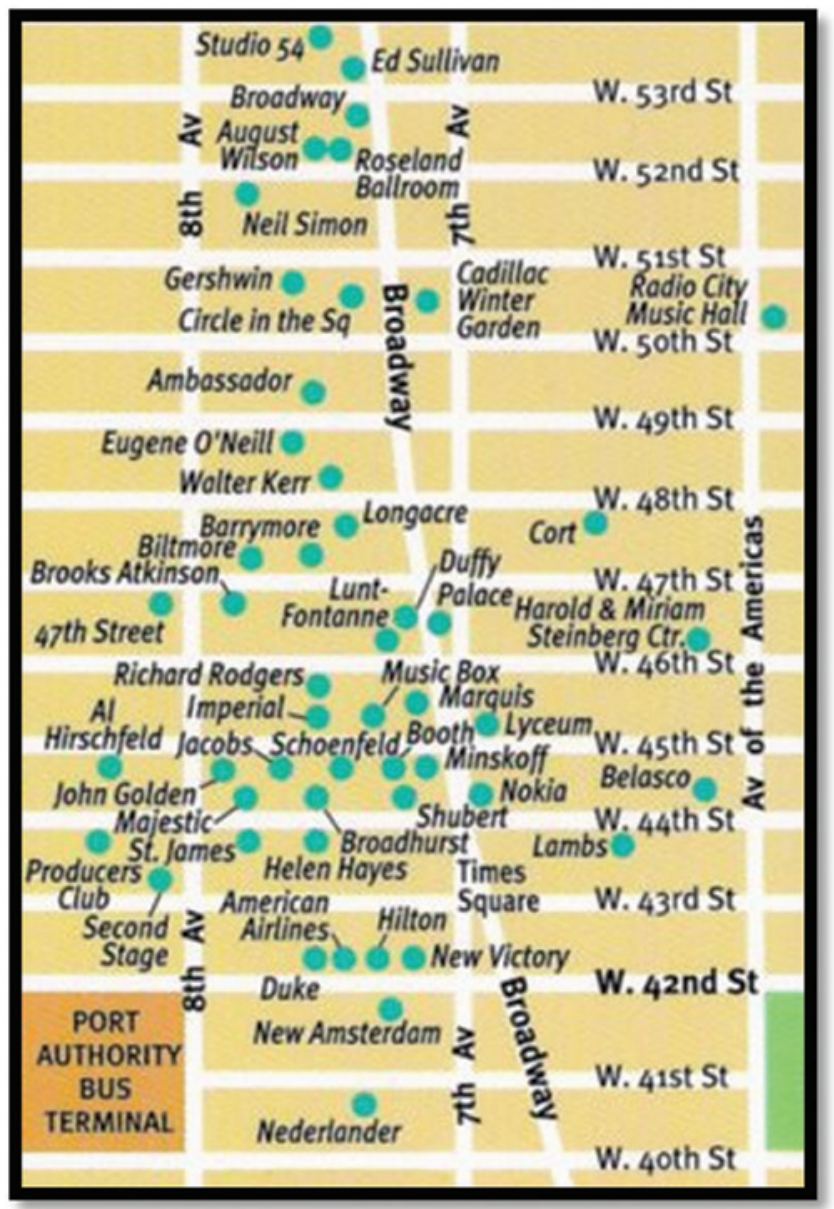

Figure 1. The Theater District, New York City.

Source. New York Insider Guide (https://www.nycinsiderguide.com/new-york-broadway-shows).

Broadway theaters. The Shubert Organization (http://www.shurbert.nyc/) currently owns seventeen theaters; The Nederlander Organization (http://www.nederlander.com/) owns nine, and Jujamcyn (http://www.jujamcyn.com/) owns five. ${ }^{18}$ The Shubert Organization also owns six Off-Broadway theaters,$^{19}$ while The Nederlander Organization owns seventeen additional theaters around the United States and three theaters in London's West End. ${ }^{20}$ Owners of Broadway theaters generally serve as landlords, renting out their theatrical space to specific shows for either finite or open-ended runs-shows that theater owners usually have no hand in developing. However, Jujamcyn Theaters operates slightly differently than Shubert or Nederlander, as producer Jordan Roth owns a majority stake in the company and actively develops productions to stage in Jujamcyn Theaters. ${ }^{21}$

While Broadway shows are usually shepherded by one or two lead producers, the money to fund these productions is often raised by these lead producers from hundreds of individual investors. For the most part, these investors must be accredited, meaning that they must meet certain financial requirements in order to invest. ${ }^{22}$ Investing in a Broadway production is a risky venture. According to Joshua Rogers of Forbes, the chances of recouping one's principal investment are one in five, while the odds of actually making a profit are even slimmer. 
While successful plays and musicals can result in high returns for backers, the chances of reaching the financial heights of a mega-hit like Hamilton are low. ${ }^{23}$

The success of a Broadway show can result in subsidiary rights, licensing, and rights to invest in the national tours and international productions. The originating production can spawn additional companies that may stay in specific cities or may take the show on the road to tour nationally or internationally. Each of these additional companies pays royalties and some net profits back to the originating production. While there are some subsidiary productions or activities that a producer may not have the rights to, such as a movie adaptation, the originating production still receives a percentage of the show's author's (or authors') profits for that subsidiary activity for a period of time after the production closes (typically between seven and thirty years). ${ }^{24}$

The mounting of shows with additional companies, whether touring or sitting down in other major urban centers for extended runs, requires negotiations and contracts with new casts and crews, other theaters, transportation companies, hotels, and more. Broadway musicals often release an original cast recording, the production of which necessitates business relationships with not only recording studios but also record labels. ${ }^{25}$ Companies such as Broadway Licensing (https://broadwaylicensing.com/), Theatrical Rights Worldwide (http://www. theatricalrights.com/), and Music Theatre International (https://www.mtishows.com/) partner with authors and producers to protect copyrights for their theatrical properties and develop, license, and distribute their performance material to professional tours, community theaters, and educational performances. Licensing increases revenue for writers, composers, and producers - for example, producers of a Broadway show may receive 30-40 percent of licensing revenue for years after the close of a show. ${ }^{26}$ Similarly, companies like Samuel French Publishing (http://www.samuelfrench.com/) have published extensive catalogs of plays, particularly of American and British dramas. ${ }^{27}$ Along with the licensed material needed to perform musicals and plays, the music print publishing industry, led by Hal Leonard (https://www.halleonard.com/), benefits from publishing individual pieces, scores, and collected song books for vocal and instrumental performance. Thus, as is the case across the media industries more generally, holding IP and granting licensing is becoming an evermore attractive and integral part of doing business in the theater industry. The built-in audiences for established IP and the ability to license that IP to other media and merchandising has resulted in an increase in musicals adapted from well-known films and jukebox musicals from successful pop artists such as ABBA and Billy Joel.

For independent theater producers, arranging and securing licensing and distribution deals with myriad companies in order to maximize profits and visibility is difficult. For companies such as Disney, which develops its own animated and live action film properties into stage musicals, the licensing of its material is about maximizing their brand and activating each possible arm of the massive media conglomerate. Financially lucrative and horizontally integrated, an entertainment corporation like Disney does not require outside help to produce their shows, as it has millions of dollars at its disposal to spend on developing their films into stage musicals or developing entirely new productions. Furthermore, Disney has decades of established relationships with other companies and experience in licensing their IP, while owning many different types of companies themselves that aid in synergistic expansion across multiple platforms and markets. They own recording studios and labels to record and 
release cast albums, and media outlets such as television networks, radio, and print publications through which to promote their shows and any ancillary products. Disney can more easily afford to advertise their properties nationally, internationally, and for longer periods of time. The reach of a media conglomerate extends far beyond the capabilities and access of independent producers. ${ }^{28}$

Following Disney's lead, since the early 2000s media corporations began to make major investments in the theatrical industry. Most notably, Universal Pictures invested US\$10 million of Wicked's total US\$14 million budget, which as of October 2018 earned US\$4.6 billion worldwide. ${ }^{29}$ Clear Channel Entertainment, Cablevision, and News Corporation have invested in theater ownership and surrounding real-estate, and have purchased advertising space on facades of Times Square buildings. ${ }^{30}$ Doing business as Live Nation Entertainment, Clear Channel has produced Broadway shows such as The Producers, Dirty Rotten Scoundrels, Caroline, or Change, Thoroughly Modern Millie and a number of popular revivals (such as Sweet Charity and 42nd Street) since the early 2000s. Clear Channel also owns more than fifty touring venues in the United States, and uses touring companies of its Broadway shows to "feed the road." 31 Clear Channel Spectacolor, the division of Clear Channel Outdoor involved in the types of spectacular advertising displays seen in Times Square, eventually got into the stage production game as well by joining the production team of the 2014 musical Side Show. ${ }^{32}$ According to Steve Adler in On Broadway: Art and Commerce on the Great White Way:

The presence over the last decade of Disney, Clear Channel Entertainment (and its predecessors), Stage Holding, Andrew Lloyd Webber's Really Useful Group, Madison Square Garden Productions, and the now defunct Livent has occasioned a series of prognostications that the pendulum is swinging inexorably in the direction of corporate hegemony. A new lexicon, with terms like vertical integration, synergy, product, focus groups, and corporate branding, has found its way onto the street. The entry of corporations into what was essentially a boutique industry has raised questions about the future of Broadway among not only independent producers-who would seem the most threatened by competition-but also artists, union leaders, and other theatre practitioners. ${ }^{33}$

Adler adds,

Many theatre executives predict, with some trepidation, that corporate producers, and thus independents who will have to keep pace, will create works that cater to audiences' growing appetite for sensational effects and easy, accessible fare. As more film studios seek to exploit their movie holdings and explore producing on the legitimate stage, this movement may gain momentum. ${ }^{34}$

Although the spectacular scale and scope of Broadway productions dates back to the days of P.T. Barnum, the presence of corporations in Times Square has resulted in significant industrial changes specifically because large corporations simply have more money to spend. Shows cost more to produce, but can also play houses longer, reach a broader audience, and extend their lives on tour or sit-down productions around the world.

The involvement of major media conglomerates in Broadway production flourished in the 1990s as Times Square was re-developed from a crime-ridden district into a family-friendly neighborhood. Since then, Hollywood has looked to Broadway with greater frequency, with the number of movie to musical adaptations on the rise (such as Rocky, Groundhog Day, and Once) and more individual producers expanding their resumes by investing in 
Broadway shows. ${ }^{35}$ In recent years, high-profile film producers such as Scott Rudin (The Book of Mormon, as well as revivals of Fences and Hello Dolly! among others), Marc Platt (Wicked), NBC Entertainment president Robert Greenblatt (A Gentleman's Guide to Love E Murder), and Universal Pictures president Jimmy Horowitz have all invested in Broadway musicals and plays, while Warner Bros. Theatre Ventures has found success with The Curious Incident of the Dog in Night-Time on Broadway and Charlie and the Chocolate Factory in the West End. A number of successful Hollywood producers got their start in Broadway and then moved west, from Paula Wagner and Sony's Lia Vollack to Craig Zadan and Neil Meron, who produced NBC's live telecasts of The Sound of Music, Peter Pan, and The Wiz. ${ }^{36}$ In short, Hollywood companies and producers are extending their involvement with Broadway, hoping to expand the lives and revenue streams of older film properties while also making investments in Broadway hits from producers with Hollywood pedigrees, like Wicked and The Book of Mormon. But this exchange between Hollywood and Broadway does not only go one way. In what follows, I briefly elucidate three ways that Broadway has adapted Hollywood's industrial strategies to try and reach broader audiences and generate new revenue streams.

\section{Streaming Services}

In the early years of television, theater-particularly plays, not musicals-were a great source of material for the new medium, though never to the extent that theater provided material for radio programming. From 1952 to 1954, local New York City station WWOR syndicated a one-hour anthology program, Broadway Television Theater, with the aim to provide nationwide access to the city's theater scene. While notable plays such as The Front Page were filmed, these were abridged versions, sliced down to one hour for broadcast. Other programs such as The Ford Theater Hour (CBS 1948-1951) and The Chevrolet Tele-Theater (NBC 1948-1950), and General Electric Theater (CBS 1953-1962) often filmed plays with Broadway actors, but also adapted films and short stories. By the early 1960s, the theatrical-based anthology series was all but gone. Broadway shows were shown only intermittently on television; from 2000 onward, they most likely appeared on premium cable channels like Showtime or HBO. ${ }^{37}$ However, even on these pay channels, one is much more likely to find film adaptations of Broadway plays and musicals rather than live broadcasts, such as Wit (HBO 2001) or Angels in America (HBO 2003). Broadway plays and musicals remain largely relegated to PBS on shows like Great Performances (1975-present).

One outlier in the history of anthology dramas is Tonight on Broadway, a half-hour weekly program on CBS that ran from 1948-1950. Tonight on Broadway showed a series of excerpts from Broadway plays and musicals, interspersed with brief interviews with actors and actresses promoting their shows. This format lives on in Broadway.com's The Broadway Channel, which promotes Broadway, Off-Broadway, and some London West End shows through a series of talk shows and excerpts. The Broadway Channel usually airs on airplane and hotel televisions as a form of tourism advertisement. However, the Broadway Channel in 2016 expanded to provide on-demand content for over the top (OTT) platforms such as Apple TV, Roku, and Fire TV. ${ }^{38}$ Broadway Direct also engages in this same type of advertising via its website but has not expanded to television or OTT platforms. 
Yet neither The Broadway Channel nor Broadway Direct provide access to complete Broadway shows; essentially their websites and TV channels operate as paratexts surrounding the shows themselves, working solely to generate consumer interest and increase ticket sales. The Broadway Television Network, which had a short-lived life as a pay-per-view channel in 2000, attempted to move beyond mere advertising to present filmed performances such as Smokey Joe's Cafe. Broadway Digital Entertainment, another outlet that emerged in the early 2000s, aimed to produce original Broadway shows that it would sell simultaneously to home viewers. ${ }^{39}$ Both ventures failed.

Broadway moved into the arena of streaming services with BroadwayHD, a subscriptionbased OTT platform that offers an archive of older recordings of Broadway, Off-Broadway, and West End plays and musicals, as well as livestreams of current shows. Billed as "a Netflix for Broadway," their slogan-"If you can't get to Broadway, get to BroadwayHD"-promises the theater experience from the comfort of your own home. Though founded in 2013 by veteran Broadway producers Bonnie Comley and Stewart Lane, it wasn't until 2015 that BroadwayHD began strongly marketing itself as a streaming service. ${ }^{40}$ As of 2018, BroadwayHD's archive of filmed productions remains rather limited, and its June 30th, 2016 stream of She Loves Me was its first livestreamed show. The service has since livestreamed Holiday Inn, Richard Nelson's The Gabriels: Election Year in the Life of One Family, and the Off-Broadway musical Ernest Shackleton Loves Me. Importantly, the live-streamed shows on BroadwayHD have been shows produced on stages owned by The Roundabout Theater and The Public, the first being not-for-profit organization and the second being Off-Broadway, and neither being part of the three large organizations that dominate the Broadway industry.

Whether BroadwayHD will continue to grow and expand its catalog and livestream offerings or whether it will be another failed effort on the part of the theatrical industry to tap into the at-home audience remains to be seen. In October 2017, BroadwayHD lowered its subscription price from US\$14.99/month to US\$8.99/month and partnered with Amazon to have its own channel that can be accessed on all US based Amazon devices. BroadwayHD also partnered with Ericsson to pre-load the BroadwayHD service on all Ericsson-connected televisions beginning in December 2017. ${ }^{41}$ With Netflix entering into the fray in 2018 with the addition of filmed productions of Oh, Hello on Broadway, Newsies: The Broadway Musical, and Springsteen on Broadway, BroadwayHD now faces stronger competition. ${ }^{42}$ That a production like Newsies, which originated its Broadway run with the Nederlander organization, has made a streaming rights deal with Netflix rather than BroadwayHD perhaps portends trouble for BroadwayHD's ability to tap major, current productions for its streaming service.

\section{Theatrical Exhibition}

The US theater industry has not limited itself to television and OTT platforms as it looks to expand its potential audience. The conversion of theaters to digital projection and distribution, which began in the early 2000s, has allowed for live digital broadcast into cinemas. Since 2006 NCM Fathom Events has partnered with the Metropolitan Opera and Lincoln 
Center to broadcast via satellite live performances of opera to movie theaters nationwide, which, according to reports by The New York Times, has been wildly successful in increasing revenue streams for the Met. ${ }^{43}$ Fathom events is owned by AC Jv LLC, which essentially gives Fathom access to the three largest cinema exhibition chains in the United States: AMC, Cinemark, and Regal Entertainment. ${ }^{44}$ These special events demand higher ticket prices and are only offered in limited showings, the better to create a sense of exclusivity and urgency for theatergoers. Although opera is certainly not characterized as Broadway and I do not mean to collapse the two, the manner in which the Metropolitan Opera has attempted to take advantage of developments in broadcasting live to movie theaters is influencing theater industries both domestically and abroad.

The National Theatre in London followed the Met's example in 2009 with National Theatre Live, working with the distribution company BY Experience to show over hundred productions of theater and opera to theaters around the globe, as well as into classrooms within the United Kingdom. ${ }^{45}$ NT Live's first broadcast, Phèdre, was shown in over two hundred cinemas around the world. By NT Live's third season, those numbers had increased to seven hundred cinemas in twenty-two countries. ${ }^{46}$ While the National Theatre's title might lead one to believe that their offerings are limited to UK productions, NT Live has offered Broadway productions, such as 2014's staging of Of Mice and Men.

Seeing the financial success of the National Theatre and the Met's live performance broadcasts to movie theaters, why then has Broadway been slow to follow its example? The Metropolitan Opera and the National Theatre are singular organizations able to exert more control and make unilateral moves. Broadway has been slower to get involved with theatrical exhibition not only out of fear that easier access might drive down ticket sales, but also because theaters are owned by numerous different people, organizations, and companies, all of whom would need to negotiate not only with theatrical distribution companies but also notoriously difficult Broadway unions. Broadway Near You, which began operation in 2010, aimed to present filmed performances from Broadway, Off-Broadway, and West End first into movie theaters nationwide before then repurposing them to air on television. Working with Lincoln Center Theater, the Ambassador Theater Group and Jeffrey Richards Associates, Broadway Near You was able to secure a fair number of filmed plays, but not musicals, and their offerings were not current-their website has not been updated since 2015 and still prominently advertises the 2013 production of Driving Miss Daisy. After a short run in theaters, Broadway Near You then moved material to PBS at a later date; Miss Daisy, for example, aired in theaters in summer 2014 and then on PBS in summer 2015. According to Bloomberg, the company is still in business, yet the production and release of content is currently at a standstill, perhaps due to the aforementioned difficulties in negotiating with Broadway power players. ${ }^{47}$

Fathom Events has been more successful than Broadway Near You, bringing performances of George Takei's Allegiance and Disney's Newsies to movie theaters nationwide in 2017. With Allegiance bringing in over US\$740,000 for one day engagement in 476 theaters, ${ }^{48}$ and Newsies raking in US\$2.5 million over two days in 780 theaters, ${ }^{49}$ it's clear that there is money to be made if Broadway is able to sufficiently engage with mechanisms of film distribution and exhibition in order to attract audiences outside of prominent theater districts in urban centers. 


\section{The Chinese Market}

Another avenue pointed toward by Hollywood is the burgeoning Chinese market. Despite severe ethical issues regarding engaging with a totalitarian regime, China is now the world's second-largest economy and on the world stage, its financial power most often outweighs its human rights violations. ${ }^{50}$ According to Stein Ringen, professor emeritus at the University of Oxford and author of The Perfect Dictatorship: China in the 21st Century, "Businesses around the world and their governments avoid anything that can cause the Chinese displeasure. They sign up to Beijing's version of the 'one China policy,' shun the Dalai Lama and stay silent on human rights abuses." ${ }^{51}$ However, with its quotas on imported films easing and movie attendance in the country on the increase, Chinese theatergoers represent a huge potential revenue stream for the US film industry that its media conglomerates have not ignored. $^{52}$ Films like Iron Man 3 (2013), Dr. Strange (2016), and The Great Wall (2016) have explicitly pandered to Chinese interests and demographics, while producers behind Iron Man 3 and Transformers: Age of Extinction (2014) have attempted to capitalize Sino-US production partnerships in order to negotiate strict governmental policies and ease the way for each film to enter the Chinese theatrical film market. ${ }^{53}$ These efforts have paid off substantially particularly for companies like Disney, which placed three films-Zootopia (2016), Captain America: Civil War (2016), and The Jungle Book (2016)-in the top 10 box office earners in China in $2016 .{ }^{54}$

For the theater industry, China also represents an opportunity to grow audiences and profits. In China, demand for Western theater has increased as Maoist-era governmental restrictions have eased. Since 2008, lavish, state-of-the art theater complexes have been built in major cities like Beijing and Shanghai, ${ }^{55}$ the Beijing Dance Academy and the Shanghai Conservatory of Music training performers ready to dance, sing, and act for Western musical theater and Chinese entertainment companies such as AC Orange International which have already invested in Broadway musical productions in the United States are now investing in touring US productions within China. ${ }^{56}$

Despite this enthusiasm, bringing Broadway musicals to China is not without its challenges, although Broadway remains a leading source of material as original productions are difficult to cultivate in a still developing home industry. ${ }^{57}$ However, imported and translated productions are extremely costly, with translations often losing clarity and specificity with that shift. ${ }^{58}$ Sino theatrical production companies have been only moderately successful in the task of importing and re-orienting Broadway musicals for the Chinese stage. Among the more successful companies is Seven Ages, which first imported a Mandarin-subtitled Man of La Mancha in 2012, followed by a translated production. Since then, Seven Ages has also translated and culturally adjusted productions of Avenue Q, How to Succeed in Business Without Really Trying, and The Sound of Music. ${ }^{59}$

Filmed productions are currently a great way to satisfy an audience seeking a wider variety of plays and musicals, as they present less financial risk and challenge than imported and translated productions. While some Broadway theater owners like The Nederlanders and producers like Cameron Mackintosh have in the past staged and continue to attempt to stage live musicals within China, filmed entertainment is a less financially risky venture. ${ }^{60}$ 
National Theatre Live found great success distributing in China the Benedict Cumberbatch and Jonny Lee Miller headlined production of Frankenstein, as well as Cumberbatch's version of Hamlet, partially because of Cumberbatch's star cachet in the nation due to the highly pirated British Broadcasting Corporation (BBC) drama Sherlock. ${ }^{61}$ Companies like Broadway Asia and Broadway Worldwide Entertainment Media's (BWEM) Direct from Broadway brand now specialize in distributing digital theater specifically within China, particularly proven mainstream fare like Rodgers \& Hammerstein's Cinderella, The Sound of Music, Smokey Joe's Cafe, and An American in Paris. ${ }^{62}$

In addition to appealing to audiences in China, Broadway is also making specific overtures to Chinese tourists within the United States. In 2016, Broadway Inbound, a branch of the Broadway stalwart Shubert Organization, partnered with Shanghai-based marketing firm Contineo to conduct outreach to the nearly million Chinese tourists visiting New York City each year. ${ }^{63}$ As Variety reports, recent relaxations of Visa restrictions has increased the number of Chinese travelers to the United States. ${ }^{64}$ Partnerships such as the one between Broadway Inbound-Contineo can increase the visibility of Broadway musicals and plays in Chinese travel publications, which in turn can increase advance ticket sales as travelers plan their trips. With projected estimations that the number of Chinese tourists visiting New York City in 2018 will exceed one million, investments in advertising Broadway shows in their home venue, rather than or in addition to importing shows to China, will also pay great dividends. $^{65}$

\section{Conclusion}

Broadway's use of these distribution and exhibition strategies integrated from the media industries is still a relatively new development. It is unclear whether these approaches will be successful and mark a lasting shift in the way that Broadway does business, or, like earlier instances of Broadway turning to film and television in the past, will cycle and fade away. There does seem to be a shift in terms of the industry's former reluctance to make use of the film and television industries' strategies in an attempt to expand their audience and generate revenue. However, this shift is tentative, with the major players such as the Shubert Organization, the Nederlander Organization, and Jujamcyn letting smaller organizations such as The Roundabout Theatre Company take risks with Broadway-originated companies such as BroadwayHD, while they prefer to take limited steps forward with more established companies like Netflix and Fathom Events. This perhaps makes the study of Broadway's integration of Hollywood methods of distribution and exhibition even more interesting, as there are ventures that are attempting to fully replicate what has worked for film and television with streaming services like BroadwayHD, while there are other attempts by Broadway to piggyback on what currently exists and has succeeded for the media industries already.

As the Broadway and Hollywood industries grow closer and boundaries begin to blur further, it will become necessary for accompanying fields of study to examine points of convergence and better engage in conversation with one another. With the livestreaming and pre-filmed 
productions of musicals and plays, streaming services are no longer restricted to film and television products, while the movie theater no longer exhibits just cinematic fare but also plays, musicals, opera, live concerts, and more. Likewise, as media studies expands its focus on the growing importance of China to the media industries, it is necessary to factor in the ways in which Broadway and other theatrical organizations complicate and nuance the discussion of the US media industries'-and the film industry in particular-outreach to that burgeoning market. As live performances begin to circulate more frequently as digital texts and reach wider and different audiences as a result of theatrical exhibition, streaming and livestreaming, media industries studies needs to more fully consider Broadway as another key player in the circulation of media texts.

${ }^{1}$ Laura E. Felschow is an Assistant Professor of Media Studies at SUNY Oneonta. Her research interests include women's and gender studies, comics studies, and production studies.

${ }^{2}$ See Anthony Bianco, Ghosts of 42nd Street: A History of America's Most Infamous Block (NY: William Morrow, 2004); Michael Reidel, Razzle Dazzle: The Battle for Broadway (NY: Simon \& Schuster, 2015); James Traub, Devil's Playground: A Century of Pleasure and Profit in Times Square (NY: Random House, 2004).

${ }^{3}$ See Barbara Wallace Grossman, "The Lion King: A 'Blockbuster Feline' on Broadway and Beyond," in The Disney Musical on Stage and Screen: Critical Approaches from "Snow White" to "Frozen," ed. George Rodosthenous (NY: Bloomsbury Methuen Drama, 2017), 117-32; Marc Miller, "Of Tunes and Toons: The Movie Musical in the 1990s," in Film Genre 2000: New Critical Essays, ed. Wheeler W. Dixon (Albany: State University of New York Press, 2000), 45-62; Maurya Wickstrom, "Commodities, Mimesis, and The Lion King: Retail Theatre for the 1990s," Theatre Journal 51 (3, October 1999): 285-98.

${ }^{4}$ Rebecca Sun, "Hamilton: Who's Making Millions Off Broadway's Hottest Show," The Hollywood Reporter, April 6, 2016, http://www.hollywoodreporter.com/news / hamilton-whos-making-millions-broadways-881205.

${ }^{5}$ Joe Otterson, "Battle of the Live Musicals: ABC Looks to Change the Game with Disney Classics," Variety, May 17, 2017, http://variety.com/2017/tv/news/broadcast-live-musicals-abc-disney-little-mermaid-1202428878/.

6 "2017-2018 Broadway End of Season Statistics," Broadway League, May 29, 2018, https://www.broadwayleague.com/press/press-releases/2017-2018-broadwayend-of-season-statistics/.

${ }^{7}$ For example, Colin MacCabe, Kathleen Murray, and Rick Warner, eds, True to the Spirit: Film Adaptation and the Question of Fidelity (NY: Oxford University Press, 2011); Steven Neale, Screening the Stage: Case Studies of Film Adaptations of Stage Plays and Musicals in the Classical Hollywood Era, 1914-1956 (New Barnet, UK: John Libbey Publishing, 2017).

${ }^{8}$ Paul McDonald, "Introduction," Cinema Journal 52 (3, Spring 2013): 145.

${ }^{9}$ Editorial Collective, "Welcome to the Media Industries," Media Industries Journal 1 (1, 2014), https://quod.lib.umich.edu/m/mij/15031809.0001.303/--industrializationand-globalization-of-chinas-musical?rgn=main;view=fulltext. 
${ }^{10}$ Matthew Freeman, Industrial Approaches to the Media: A Methodological Gateway to Industry Studies (London: Palgrave Macmillan, 2016), 3-5.

11 "Media Industries: Current Debates and Future Directions." 2018 Conference Program. https://media-industries.org/.

${ }^{12}$ Shin Dong Kim, "The Industrialization and Globalization of China's Musical Theater," Media Industries Journal 1 (3, 2015), https://quod.lib.umich.edu/m/ mij/15031809.0001.303/--industrialization-and-globalization-of-chinas-musical? rgn=main; view=fulltext.

${ }^{13}$ Robert Viagas, "How to Tell Off-Broadway From..." Playbill, January 4, 1998, http://www.playbill.com/article/how-to-tell-broadway-from-off-broadwayfrom-com-110450.

14 Ibid.

15 "About the League," The Broadway League, https://www.broadwayleague.com/ about/.

${ }^{16}$ Ibid.

17 "Work at a LOTR Theatre," http://lort.org/work.

${ }^{18}$ Internet Broadway Database-Theatres, https://www.ibdb.com/theatres/\#nyc.

19 "The Shubert Organization-About Us," http://shubert.nyc/about-us/.

20 "Nederlander-Venues," http://www.nederlander.com/venues.html.

${ }^{21}$ Jesse Oxfeld, "A Day in the Life of Jordan Roth," The Wall Street Journal, August 1, 2016, https://www.wsj.com/articles/a-day-in-the-life-of-jordan-roth-1470071341.

${ }^{22}$ Ken Davenport, "10 FAQ About Broadway Investing," The Producer's Perspective, https://www.theproducersperspective.com/my_weblog/2016/01/10-faqabout-broadway-investing.html.

${ }^{23}$ Joshua Rogers, "Invest In The Next 'Hamilton'? Broadway's Odds Look Like Silicon Valley's," Forbes, May 31, 2016, https://www.forbes.com/sites/joshuarogers /2016/05/31/invest-in-the-next-hamilton-broadways-odds-look-like-sil icon-valleys /\#6574fe417ed3.

${ }^{24}$ Davenport, "10 FAQ About Broadway Investing."

${ }^{25}$ Jesse Green, "Why Does Nearly Every Broadway Show Still Release a Cast Album?" Vulture, October 6, 2015, http://www.vulture.com/2015/10/broadway-showscast-albums.html.

${ }^{26}$ Jim Rendon, "Broadway Hits the Middle School Circuit," The New York Times, February 23, 2018, https://www.nytimes.com/2018/02/23/business/broadwayhits-the-middle-school-circuit.html.

27 "Samuel French: House of Plays," http://www.samuelfrench.com/history.

${ }^{28}$ Elizabeth L. Wollman, A Critical Companion to the American Stage Musical (NY: Bloomsbury Methuen Drama, 2017): 176.

${ }^{29}$ Marc Hershberg, "NBCUniversal Basks in Own Success with 'Wicked' Anniversary Telecast," Forbes, October 29, 2018, https://www.forbes.com/sites/marchershberg/2018/10/29/nbcuniversal-basks-in-own-success-with-wicked-anniver sary-telecast/\#4c7e63fe3a5b.

${ }^{30}$ Elizabeth L. Wollman, "The Economic Development of the 'New' Times Square and Its Impact on the Broadway Musical," American Music 20 (4, Winter 2002): 448. 
${ }^{31}$ Steven Adler, On Broadway: Art and Commerce on the Great White Way (Carbondale: Southern Illinois University Press, 2004), 21.

32 "In Its First Ever Theatrical Venture, Clear Channel Spectacolor Joins the Producing Team of 'Side Show,' Clear Channel Outdoor, September 25, 2014, http://company. clearchanneloutdoor.com/first-ever-theatrical-venture-clear-channel-spectacolor-joins-producing-team-side-show /.

${ }^{33}$ Adler, On Broadway, 67.

${ }^{34}$ Ibid., 101.

${ }^{35}$ Michele Willens, "Is Broadway Being Destroyed by Hollywood?" The Daily Beast, March 17, 2014, https://www.thedailybeast.com/is-broadway-being-destroyedby-hollywood.

${ }^{36}$ Gordon Cox, "Hollywood \& Broadway: Studios Rush to the Stage Despite Clashing Business Models," Variety, April 7, 2015, http://variety.com/2015/legit/news / hollywood-broadway-studios-rushing-to-the-stage-despite-clashing-businessmodels-1201467028/.

${ }^{37}$ Paula Bernstein and Tom Tapp, "HBO, Showtime to Go Legit," Variety, May 4, 2000, http://variety.com/2000/legit/news/hbo-showtime-go-legit-1117821212/.

${ }^{38}$ Gordon Cox, "The Broadway Channel Goes Over the Top on Apple TV, Roku, Fire TV," Variety, June 15, 2016, http://variety.com/2016/legit/news/broadway-chan nel-apple-tv-roku-fire-1201796082/.

${ }^{39}$ Bruce Weber, "Taking the Show to Television," Variety, January 19, 2000, http:// www.nytimes.com/2000/01/19/theater/taking-the-show-to-television.html.

${ }^{40}$ Emma Lord, "BroadwayHD, A Netflix for Broadway, Is about to Defy So Much More Than Gravity," Bustle, October 27, 2015, https://www.bustle.com/articles/119662broadway-hd-a-netflix-for-broadway-is-about-to-defy-so-much-more-thangravity.

${ }^{41}$ Olivia Clement, "BroadwayHD Partners with Amazon and Ericsson," Playbill, October 19, 2017, http://www.playbill.com/article/broadwayhd-partners-withamazon-and-ericsson.

${ }^{42}$ Andrew Gans, "Nick Kroll and John Mulaney's Oh, Hello on Broadway Sets Netflix Premiere Date," Playbill, May 18, 2017, http://www.playbill.com/article/nick-krolland-john-mulaneys-oh-hello-on-broadway-sets-netflix-premiere-date; Andrew Gans and Adam Hetrick, "Disney's Newsies: The Broadway Musical Available to Stream on Netflix Sept. 5," Playbill, September 5, 2017, http://www.playbill.com/ article/disneys-newsies-the-broadway-musical-available-to-stream-on-netflixsept-5.

${ }^{43}$ Charles Isherwood, "Off Off Off Broadway (at Your Multiplex)," New York Times, January 23, 2014, https://www.nytimes.com/2018/02/23/business/broadwayhits-the-middle-school-circuit.html.

${ }^{44}$ Mark Harden, "Fathom Events Names Anschutz Exec Its First Post-Spinoff CEO," Denver Business Journal, April 3, 2014, http://www.bizjournals.com/denver/blog/ broadway_17th/2014/04/fathom-events-names-anschutz-exec-its-first-post. html.

${ }^{45}$ Isherwood, "Off Off Off Broadway (at Your Multiplex)."

46 "National Theatre Live: About Us," http://nationaltheatre.org.uk. 
47 "Company Overview of Broadway Near You LLC," Bloomberg, http://www.bloom berg.com/research/stocks /private/snapshot.asp?privcapId = 238475269 .

48 "George Takei's Allegiance (2017)," Box Office Mojo, http://www.boxofficemojo. $\mathrm{com} / \mathrm{movies} /$ ?id=georgetakeisallegiance.htm.

49 "Newsies: The Broadway Musical (2017)," Box Office Mojo, http://www.boxoffic emojo.com/movies /?page=daily\&id=newsiesfathom.htm.

${ }^{50}$ Daniel Kliman and Zack Cooper, "Washington Has a Bad Case of China ADHD," Foreign Policy, October 27, 2017, http://foreignpolicy.com/2017/10/27/washing ton-has-a-bad-case-of-china-adhd/.

${ }^{51}$ Stein Ringen, "A Dazzling Spectacle of China's Totalitarianism," The Washington Post, October 17, 2017, https://www.washingtonpost.com/opinions/a-daz zling-spectacle-of-chinas-totalitarianism/2017/10/17/364bf8e4-b296-11e79e58-e6288544af98_story.html?utm_term=.9a851a4f0227.

52 Patrick Frater, "U.S. and China Struggle Over Film Quotas," Variety, February 9, 2017, http://variety.com/2017/biz/asia/u-s-and-china-struggle-over-film-quo tas-1201979720/.

${ }^{53}$ Aynne Kokas, Hollywood Made in China (Berkeley: University of California Press, 2017), 19-39.

54 "2016 China Yearly Box Office," Box Office Mojo, http://www.boxofficemojo.com/ intl/china/yearly /?yr=2016\&p=.htm.

${ }^{55}$ See Zhang Kun, "China to have its own Broadway theatre," China Daily USA, October 14, 2016, http://usa.chinadaily.com.cn/epaper/2016-10/14/content_27062131. htm; Laura MacDonald, "The Sound of Musicals in China," American Theatre, May/ June 2017, http://www.americantheatre.org/2017/04/25/the-sound-of-musi cals-in-china/; Sheila Melvin, "So Far Off Broadway It's in China," The New York Times, December 22, 2011, http://www.nytimes.com/2011/12/23/arts/23iht chinatheater23.html; David Stanway, "China to Hear the Sound of Musicals at 32-Theatre 'Broadway' Complex," The Guardian, December 23, 2008, https:// www.theguardian.com/world/2008/dec/24/beijing-china-musicals-theatredevelopment.

${ }^{56}$ MacDonald, "The Sound of Musicals in China."

${ }^{57}$ Melvin, "So Far Off Broadway It's in China."

${ }^{58}$ Ibid.

${ }^{59}$ MacDonald, "The Sound of Musicals in China."

${ }^{60}$ Bruce Einhorn, "In China! It's a Mess!" Bloomberg, June 9, 2015, https://www. bloomberg.com/news/articles/2015-06-09/broadway-in-china-it-s-a-mess.

${ }^{61}$ Adam Taylor, "The Unreal Popularity of Sherlock in China," Business Insider, January 3, 2014, http://www.businessinsider.com/the-unreal-popularity-of-sherlock-inchina-2014-1.

${ }^{62}$ Gordon Cox, "Broadway Musicals Make Digital Push into China with New Deal," Variety, September 29, 2014, http://variety.com/2014/legit/news/broadwaymusicals-direct-from-broadway-china-1201316298/.

${ }^{63}$ Gordon Cox, "Broadway Sets Its Sights on Chinese Tourists," Variety, August 11, 2016, http://variety.com/2016/legit/news/broadway-chinese-tourists-1201835659/.

${ }^{64}$ Ibid. 
${ }^{65}$ Zhou Wenting, "Over 1m Chinese Tourists to Visit NY in 2018," China Daily, April 8, 2017, http://www.chinadaily.com.cn/world/2017xivisitsfinlandandus / 2017-04/08/content_28841394.htm.

\section{Bibliography}

"2016-2017 Broadway End of Season Statistics." Broadway League, May 23, 2017. https:// www.broadwayleague.com/press /press-releases /2016-2017-broadway-end-ofseason-statistics/.

"About the League." The Broadway League. https://www.broadwayleague.com/about/.

Adler, Steven. On Broadway: Art and Commerce on the Great White Way. Carbondale: Southern Illinois University Press, 2004.

Altman, Rick. The American Film Musical. Bloomington: Indiana University Press, 1988.

Anderson, Christopher. Hollywood TV: The Studio System in the Fifties. Austin: University of Texas Press, 1994.

Atkey, Mel. A Million Miles from Broadway: Musical Theatre Beyond New York and London. Delta, BC: The Friendlysong Book Company, 2012.

Atkinson, Brooks. Broadway. New York: Macmillan, 1970.

Barrios, Richard. Dangerous Rhythm: Why Movie Musicals Matter. New York: Oxford University Press, 2014.

Berger, Glen. Song of Spider-Man: The Inside Story of the Most Controversial Musical in Broadway History. New York: Simon \& Schuster, 2013.

Bernstein, Paula and Tom Tapp. "HBO, Showtime to go legit." Variety, May 4, 2000. http:// variety.com/2000/legit/news/hbo-showtime-go-legit-1117821212/.

Bianco, Anthony. Ghosts of $42^{\text {nd }}$ Street: A History of America's Most Infamous Block. New York: William Morrow, 2004.

Boddy, William. Fifties Television: The Industry and its Critics. Champaign: University of Illinois Press, 1992.

Box Office Mojo. "2016 China Yearly Box Office.” Box Office Mojo. http://www.boxofficemojo.com/intl/china/yearly /?yr=2016\&p=.htm.

Cohan, Steve. The Sound of Musicals. London: BFI, 2010.

Cohan, Steve, ed. Hollywood Musicals: The Film Reader. New York: Routledge, 2002.

Cox, Gordon. "The Broadway Channel Goes Over the Top on Apple TV, Roku, Fire TV." Variety, June 15, 2016. http://variety.com/2016/legit/news/broadway-channel-apple-tvroku-fire-1201796082/.

Cox, Gordon. "Broadway Musicals Make Digital Push into China with New Deal." Variety, September 29, 2014. http://variety.com/2014/legit/news/broadway-musicalsdirect-from-broadway-china-1201316298/. 
Cox, Gordon. "Broadway Sets Its Sights on Chinese Tourists." Variety, August 11, 2016. http:// variety.com/2016/legit/news/broadway-chinese-tourists-1201835659/.

Davenport, Ken. "10 FAQ About Broadway Investing." The Producer's Perspective. https:// www.theproducersperspective.com/my_weblog/2016/01/10-faq-about-broad way-investing.html.

Dunne, Michael. American Film Musical Themes and Forms. Jefferson, NC: McFarland \& Co., 2004.

Feuer, Jane. The Hollywood Musical, 2nd ed. Bloomington: Indiana University Press, 1993.

Fordin, Hugh. MGM's Greatest Musicals. Boston: De Capo Press, 1996.

Frater, Patrick. "U.S. and China Struggle Over Film Quotas." Variety, February 9, 2017. http://variety.com/2017/biz/asia/u-s-and-china-struggle-over-film-quo tas-1201979720/.

Freeman, Matthew. Industrial Approaches to the Media: A Methodological Gateway to Industry Studies. London: Palgrave Macmillan, 2016.

Gans, Andrew. "Nick Kroll and John Mulaney's Oh, Hello on Broadway Sets Netflix Premiere Date." Playbill, May 18, 2017. http://www.playbill.com/article/nick-kroll-and-johnmulaneys-oh-hello-on-broadway-sets-netflix-premiere-date.

Gans, Andrew and Adam Hetrick. "Disney's Newsies: The Broadway Musical Available to Stream on Netflix Sept. 5." Playbill, September 5, 2017. http://www.playbill.com/ article/disneys-newsies-the-broadway-musical-available-to-stream-on-netflixsept-5.

Grant, Barry Keith. The Hollywood Film Musical. Hoboken, NJ: Wiley-Blackwell, 2012.

Green, Jesse. "Why Does Nearly Every Broadway Show Still Release a Cast Album?" Vulture, October 6, 2015. http://www.vulture.com/2015/10/broadway-shows-cast-albums. html.

Griffin, Sean. Free and Easy?: A Defining History of the American Film Musical Genre. Hoboken, NJ: Wiley-Blackwell, 2018.

Grossman, Barbara Wallace. "The Lion King: A 'Blockbuster Feline' on Broadway and Beyond." In The Disney Musical on Stage and Screen: Critical Approaches from "Snow White" to "Frozen," edited by George Rodosthenous, 117-32. New York: Bloomsbury Methuen Drama, 2017.

Harden, Mark. "Fathom Events Names Anschutz Exec Its First Post-Spinoff CEO." Denver Business Journal, April 3, 2004. http://www.bizjournals.com/denver/blog/ broadway_17th/2014/04/fathom-events-names-anschutz-exec-its-first-post.html.

Hershberg, Marc. "NBCUniversal Basks in Own Success with 'Wicked' Anniversary Telecast." Forbes, October 29, 2018. https://www.forbes.com/sites/marchersh berg/2018/10/29/nbcuniversal-basks-in-own-success-with-wicked-anniversarytelecast/\#4c7e63fe3a5b.

Hilmes, Michele. Hollywood and Broadcasting: From Radio to Cable. Champaign: University of Illinois Press, 1999. 
Hilmes, Michele. Only Connect: A Cultural History of Broadcasting in the United States, 4th ed. Boston: Wadsworth Cengage Learning, 2013.

"In Its First Ever Theatrical Venture, Clear Channel Spectacolor Joins the Producing Team of 'Side Show,' Clear Channel Outdoor, September 25, 2014. http://company.clearchanneloutdoor.com/first-ever-theatrical-venture-clear-channel-spectacolor-joinsproducing-team-side-show /.

"Internet Broadway Database-Theatres." https://www.ibdb.com/theatres/\#nyc.

James, David E. Rock "n" Film: Cinema's Dance with Popular Music. New York: Oxford University Press, 2016.

Kennedy, Matthew. Roadshow!: The Fall of Film Musicals in the 1960s. New York: Oxford University Press, 2014.

Kokas, Aynne. Hollywood Made in China. Berkeley: University of California Press, 2017.

Kim, Shin Dong. "The Industrialization and Globalization of China's Musical Theater." Media Industries Journal 1, no. 3 (2015). https://quod.lib.umich.edu/m/ mij/15031809.0001.303/--industrialization-and-globalization-of-chinas-musical?rg $\mathrm{n}=$ main;view=fulltext.

Kun, Zhang. "China to Have Its Own Broadway Theatre." China Daily USA, October 14, 2016. http://usa.chinadaily.com.cn/epaper/2016-10/14/content_27062131.htm.

Lord, Emma. "BroadwayHD, A Netflix for Broadway, Is about to Defy So Much More Than Gravity." Bustle, October 27, 2015. https://www.bustle.com/articles/119662-broad way-hd-a-netflix-for-broadway-is-about-to-defy-so-much-more-than-gravity.

MacCabe, Colin, Kathleen Murray, and Rick Warner, eds. True to the Spirit: Film Adaptation and the Question of Fidelity. New York: Oxford University Press, 2011.

MacDonald, Laura. "The Sound of Musicals in China." American Theatre, May/June 2017. http://www.americantheatre.org/2017/04/25/the-sound-of-musicals-in-china/.

"Media Industries: Current Debates and Future Directions." 2018 Conference Program. https://media-industries.org/.

Meyers, Cynthia B. A Word From Our Sponsors: Admen, Advertising, and the Golden Age of Radio. New York: Fordham University Press, 2013.

Miller, Marc. "Of Tunes and Toons: The Movie Musical in the 1990s." In Film Genre 2000: New Critical Essays, edited by Wheeler W. Dixon, 45-62. Albany: State University of New York Press, 2000.

Mordden, Ethan. When Broadway Went to Hollywood. New York: Oxford University Press, 2016.

"Nederlander-Venues." http://www.nederlander.com/venues.html.

Otterson, Joe. "Battle of the Live Musicals: ABC Looks to Change the Game with Disney Classics." Variety, May 17, 2017. http://variety.com/2017/tv/news/broadcast-livemusicals-abc-disney-little-mermaid-1202428878/. 
Oxfeld, Jesse. "A Day in the Life of Jordan Roth." The Wall Street Journal, August 1, 2016. https://www.wsj.com/articles /a-day-in-the-life-of-jordan-roth-1470071341.

Reidel, Michael. Razzle Dazzle: The Battle for Broadway. New York: Simon \& Schuster, 2015.

Rendon, Jim. "Broadway Hits the Middle School Circuit." The New York Times, February 23, 2018. https://www.nytimes.com/2018/02/23/business/broadway-hits-the-mid dle-school-circuit.html.

Rodosthenous, George, ed. The Disney Musical on Stage and Screen. New York: Bloomsbury Methuen Drama, 2017.

Rogers,Joshua."InvestintheNext'Hamilton'?Broadway'sOddsLookLikeSiliconValley's."Forbes, May 31, 2016. https://www.forbes.com/sites/joshuarogers/2016/05/31/invest-inthe-next-hamilton-broadways-odds-look-like-silicon-valleys /\#6574fe417ed3.

Rubin, Martin. "Busby Berkeley and the Backstage Musical." In Hollywood Musicals: The Film Reader, edited by Steven Cohan, 53-62. New York: Routledge, 2002.

"Samuel French: House of Plays." http://www.samuelfrench.com/history.

Schatz, Thomas. "Postwar Stars, Genres, and Production Trends." In Boom or Bust: American Cinema in the 1940s, edited by Thomas Schatz, 353-96. Berkeley: University of California Press, 1997.

Schoenfeld, Gerald. Mr. Broadway: The Inside Story of the Shuberts, the Shows, and the Stars. Montclair, NJ: Applause, 2012.

Stanway, David. "China to Hear the Sound of Musicals at 32-Theatre 'Broadway' Complex." The Guardian, December 23, 2008. https://www.theguardian.com/world/2008/ dec/24/beijing-china-musicals-theatre-development.

Stempel, Larry. Showtime: A History of the Broadway Musical Theater. New York: W.W. Norton, 2010.

Sun, Rebecca. "Hamilton: Who's Making Millions Off Broadway's Hottest Show." The Hollywood Reporter, April 6, 2016. http://www.hollywoodreporter.com/news/hamilton-whosmaking-millions-broadways-881205.

Taylor, Adam. "The Unreal Popularity of Sherlock in China." Business Insider, January 3, 2014. http://www.businessinsider.com/the-unreal-popularity-of-sherlock-in-china-2014-1.

"The Shubert Organization-About Us." http://shubert.nyc/about-us/.

Traub, James. Devil's Playground: A Century of Pleasure and Profit in Times Square. New York: Random House, 2004.

Viagas, Robert. "How to Tell Off-Broadway From..." Playbill, January 4, 1998. http://www. playbill.com/article/how-to-tell-broadway-from-off-broadway-from-com-110450.

Viertel, Jack. The Secret Life of the American Musical: How Broadway Shows are Built. New York: Sarah Crichton Books, 2016.

Weber, Bruce. "Taking the Show to Television." Variety, January 19, 2000. http://www. nytimes.com/2000/01/19/theater/taking-the-show-to-television.html. 
Wenting, Zhou. "Over 1m Chinese tourists to visit NY in 2018." China Daily, April 8, 2017. http://www.chinadaily.com.cn/world/2017xivisitsfinlandandus /2017-04/08/ content_28841394.htm.

Wickstrom, Maurya. "Commodities, Mimesis, and The Lion King: Retail Theatre for the 1990s." Theatre Journal 51, no. 3 (October 1999): 285-98.

Wollman, Elizabeth L. "The Economic Development of the 'New' Times Square and Its Impact on the Broadway Musical," American Music 20, no. 4 (Winter 2002): 445-65.

Wollman, Elizabeth L. A Critical Companion to the American Stage Musical. New York: Bloomsbury Methuen Drama, 2017.

"Work at a LOTR Theatre." http://lort.org/work. 